\title{
Incorporation of n-3 Fatty Acids by the Liver of Mice Fed Linseed Oil as a Function of Feeding Duration
}

\author{
João Angelo Lima Perini ${ }^{1}$, Flávia Braidotti Stevanato ${ }^{1}$, Jeane Eliete Laguila Visentainer ${ }^{2}$, \\ Sheisa Cyléia Sargi ${ }^{2}$, Marcia Machado Oliveira ${ }^{2}$, Nilson Evelázio Souza ${ }^{1}$, Makoto \\ Matsushita $^{1}$ and Jesuí Vergílio Visentainer ${ }^{1 *}$ \\ ${ }^{1}$ Departamento de Química; Universidade Estadual de Maringá; Av. Colombo, 5.790; 87020-900; Maringá - PR - \\ Brasil. ${ }^{2}$ Departamento de Análises Clínica; Universidade Estadual de Maringá; 87020-900; Maringá - PR - Brasil
}

\begin{abstract}
The objective of this study was to evaluate the incorporation of omega-3 fatty acids (n-3 FA) on male Swiss mice livers receiving diets based on linseed oil ( $L O)$ for up to 56 days. The mice were sacrificed at 7, 14, 28, 42, 56 days and FA concentration was analyzed by gas chromatography. A total of 13 FA were identified on LO feeds presenting alpha-linolenic acid (LNA) contents of $26.97 \%$. A total 22 FA were identified in the livers of the mice. Part of the LNA was converted into n-3 FA (20:3n-3, eicosapentaenoic acid-EPA, 22:5n-3, and docosahexaenoic acid-DHA), and some of the LNA was stored in the liver. LNA, EPA and DHA concentrations (mg/g total lipids ) from 0 days for up 56 days increased from 1.29 to 18.90 (LNA), 0.20 to 18.90 (EPA) and 41.26 to 99.17 (DHA).The concentration of $n-3$ FA in the livers varied with the duration of the LO diet. During LO feed, n-6 FA concentration fell and n-3 FA concentration rose through the experimental period.
\end{abstract}

Key words: polyunsaturated fatty acids, mice, liver, linseed oil

\section{INTRODUCTION}

Mice are used in experiments because of their biological similarities to human beings. They are monogastric mammals and present metabolic routes and DNA segments similar to those of human beings (Harris, 1997; Leon, 2005). Linseed oil is the richest known source of alpha-linolenic acid (LNA, 18:3n-3), a precursor of the long chain n-3 PUFA series (de Souza et al., 2008; Tonial et al., 2009). LNA and linoleic acid (LA, 18:2n-6) are essential fatty acids and are metabolized by the same sequential desaturation and elongation enzyme systems, which results in the production of long chain polyunsaturated fatty acids (LC-
PUFA) of the n-3 and n- 6 series, respectively. The conversion into their longer chain homologues occurs by a combination of subsequent reactions involving $\Delta 6$ desaturation of LNA to $18: 4 n-3$ and of LA to $18: 3 n-6$, followed by elongation and $\Delta 5$ desaturation to eicosapentaenoic acid (EPA) and arachidonic acid (AA, 20:4n-6), which finally undergo elongation and $\Delta 4$ desaturation to produce docosapentaenoic acid (22:5n-6) and docosahexaenoic acid (DHA, 22:6n-3) (Qiu, 2003; Schaeffer et al., 2006). Currently, there is a great interest in the roles of omega-3 (n-3 LC-PUFA) and omega-6 (n-6 LC-PUFA) in human health and metabolism.

\footnotetext{
*Author for correspondence: jvvisentainer@uem.br
} 
The typical western diet has high levels of n-6 FA in the form of vegetable oils, such as sunflower oil, corn oil, cottonseed oil, and especially soybean oil, which is the most consumed oil in the world. On the other hand, lower intake of n-3 FA occurs, as for example, through the intake of linseed oil and fish oil (Visentainer et al., 2005). The level of dietary n-3 FA may be changed by the concomitant intake of other types of fats. It is recognized that n-6 and n-3 FA compete for elongation and desaturation. This competition for $\Delta 6$ desaturase affects the incorporation of n-3 LCPUFA metabolites in tissues, which affects the impact of n-3 LC-PUFA on chronic disease (James et al., 2000).

The intake of $n-6$ FA promotes the role of AA as a precursor of the 2-series prostanoids and the 4series leukotrienes in the metabolism of eicosanoids. This creates a proinflammatory, proaggregatory environment that may affect the development or progression of chronic diseases (Garófolo and Petrilli, 2006). The intake of $n-3$ polyunsaturated fatty acids (PUFA) (from linseed oil or marine oils) partially replaces the $20: 4 n-6$ in the eicosanoid metabolism, favoring the less inflammatory and aggregatory 3 -series prostanoids and 5-series leukotrienes (Surette, 2008).

The competition between n-6 and n-3 FA may be clinically important and may affect the development or progression of diseases (Vancassel et al., 2007). It is worth nothing that AA is important for fetal growth and the metabolism of prostaglandins (Calder, 2006; Innis, 2007), while among LC-PUFA, EPA and DHA have received much attention from the scientific communities because of their positive role in human health (Carl et al., 2009; Calder, 2006; Chapkin et al., 2009). Studies in humans have also demonstrated the conversion of LNA to EPA and DHA (Harnack et al., 2009).

Thus, this study aimed to evaluate the incorporation of LNA and the conversion of LNA into their long-chain homologues in the liver of mice fed linseed oil as a function of feeding time of 56 days.

\section{MATERIALS AND METHODS}

Animal and diets

Thirty-six male Swiss mice, weighing $25.0 \pm 2.0 \mathrm{~g}$ aged four weeks old were fed commercial diet supplemented with 3\% (w/w) sunflower oil (Table 1). The experiment with linseed oil diet $(3.0 \%$ w/w, Table 1) was carried out for eight weeks (56 days). The mice were randomly assigned to six groups of six specimens each in two replicates and were individually kept in polycarbonate cages and fed linseed oil diets ad libitum. The temperature was controlled at $23-24^{\circ} \mathrm{C}$ with 12 -h light/dark cycles. This study was performed in accordance with the guidelines of the Ethics Committee for Research with Animals of UEM (No. 9751/2007PRO), according to Brazilian Laws.

On the first day, six mice were sacrificed, starting at day zero (before the beginning of the treatments with linseed oil) and every day thereafter (7, 14, $28,42,56$ days). After the mice were killed, the liver was removed and kept in polyethylene bags in $\mathrm{N}_{2}$ atmosphere at $-18^{\circ} \mathrm{C}$. In the beginning of each analysis, the liver samples were allowed to equilibrate to room temperature, diced, and homogenized.

Total lipids, moisture, and fatty acid composition

Total lipids (TL) in the liver and feed were determined according to Bligh and Dyer (1959) and moisture, according to Cunniff (1998). Fatty acid methyl esters (FAME) were prepared by methylation of total lipids by Maia and RodriguezAmaya (1993). The methyl esters were separated by gas chromatography using a Varian 3300 (USA) gas chromatograph fitted with a flame ionization detector (FID) and a fused-silica CPselect CB-Fame capillary column (100 m x 0.25 $\mathrm{mm}$ id., $0.25 \mu \mathrm{m}$ cyanopropyl CP-7420) (Martin et al., 2008). Injector and detector temperatures were at $240{ }^{\circ} \mathrm{C}$. The column temperature was maintained at $165^{\circ} \mathrm{C}$ for $12 \mathrm{~min}$ and programmed from 165 to $180^{\circ} \mathrm{C}$ at $40^{\circ} \mathrm{C} / \mathrm{min}$ for $15 \mathrm{~min}$ and from 180 to $240{ }^{\circ} \mathrm{C}$ at $15^{\circ} \mathrm{C} / \mathrm{min}$ to $18 \mathrm{~min}$. The ultra-pure gas flows were: $1.4 \mathrm{~mL} \cdot \mathrm{min}^{-1}$ carrier gas (hydrogen), $30 \mathrm{~mL} \cdot \mathrm{min}^{-1}$ make-up gas (nitrogen), $300 \mathrm{~mL} \cdot \mathrm{min}^{-1}$ synthetic air and $30 \mathrm{~mL} \cdot \mathrm{min}^{-1}$ hydrogen flame gas, split injection, 1:100 ratio. Samples were injected in triplicate. Retention times and peak area $\%$ values were automatically computed by a Varian 4290 integrator. For the identification of fatty acids, fatty acid retention times were compared to those of standard methyl esters (Sigma, USA). 
Table 1 - Composition, total lipid content, and fatty acid composition of the experimental diets

\begin{tabular}{lcc}
\hline \multicolumn{1}{c}{ Ingredients $(\%$ w/w) } & Commercial diet & Linseed oil diet \\
\hline Soybean meal & 37.4 & 37.4 \\
Wheat meal & 6.9 & 6.9 \\
Ground corn & 45.0 & 45.0 \\
Linseed oil & 0.0 & 3.0 \\
Sunflower oil & 3.0 & 0.0 \\
Bicalcium phosphate & 2.5 & 2.5 \\
Calcareous & 0.4 & 0.4 \\
NaCl & 0.3 & 0.3 \\
Premix & 4.5 & 4.5 \\
\hline Total lipids (\%) & $7.76 \pm 0.53$ & $7.60 \pm 0.68$ \\
\hline Fatty acid composition ${ }^{\mathrm{b}}$ & Means $\pm \mathrm{SD}$ & Means $\pm \mathrm{SD}$ \\
\hline $14: 0$ & $0.20 \pm 0.01^{\mathrm{a}}$ & $0.13 \pm 0.02^{\mathrm{b}}$ \\
$16: 0$ & $12.08 \pm 0.23^{\mathrm{a}}$ & $11.29 \pm 0.08^{\mathrm{b}}$ \\
$16: 1 \mathrm{n}-7$ & $0.14 \pm 0.01$ & $0.13 \pm 0.03$ \\
$17: 0$ & $\operatorname{tr}$ & $0.08 \pm 0.03$ \\
$18: 0$ & $3.06 \pm 0.0^{\mathrm{a}}$ & $3.74 \pm 0.03^{\mathrm{b}}$ \\
$18: 1 \mathrm{n}-9$ & $23.34 \pm 0.03^{\mathrm{a}}$ & $22.28 \pm 0.03^{\mathrm{b}}$ \\
$18: 2 \mathrm{n}-6$ & $57.09 \pm 0.27^{\mathrm{a}}$ & $34.69 \pm 0.03^{\mathrm{b}}$ \\
$18: 3 \mathrm{n}-3$ (LNA) & $2.92 \pm 0.01^{\mathrm{a}}$ & $26.97 \pm 0.11^{\mathrm{b}}$ \\
$20: 1 \mathrm{n}-9$ & $0.24 \pm 0.05$ & $0.23 \pm 0.01$ \\
$22: 0$ & $0.38 \pm 0.05^{\mathrm{a}}$ & $0.20 \pm 0.01^{\mathrm{b}}$ \\
$22: 1 \mathrm{n}-9$ & $0.17 \pm 0.07$ & tr $^{\mathrm{a}}$ \\
$22: 2 \mathrm{n}-6$ & $0.17 \pm 0.03^{\mathrm{a}}$ & $0.09 \pm 0.02^{\mathrm{b}}$ \\
$24: 0$ & $0.21 \pm 0.04$ & $0.17 \pm 0.03$
\end{tabular}

${ }^{\mathrm{A}}$ Premix. Vitamin and mineral supplements per Kg: Vit. A (500.000 UI), Vit. D3 (200.000 UI), Vit. E (5.0 g), Vit. K3 (1.0 g), Vit. B1 (1.5 g), Vit. B2 (1.5 g), B6 (1.5 g), B12 (4.0 g), Vit. C (15.0 g), Folic acid (500 mg), Pantotenic acid (4.0 g), BHT (17.5 $\mathrm{g})$, Biotine $(50.0 \mathrm{mg})$, Coline $(40.0 \mathrm{mg})$, Copper $(0.5 \mathrm{~g})$, Cobalt $(10.0 \mathrm{mg})$, Iron $(5.0 \mathrm{~g})$, Inositol $(10.0 \mathrm{~g})$, Iodine (50.0 mg), Manganese $(1.5 \mathrm{~g})$, Nicotinamide $(7.0 \mathrm{~g})$, selenium $(10.0 \mathrm{mg})$, Zinc $(5.0 \mathrm{~g})$. ${ }^{\mathrm{b}}$ Value expressed as percentage of total fatty acid methyl esters of six replicates analyses. Averages followed by different letters in the same line are significantly different $(\mathrm{p}<0.05)$ by Tukey's test. Abbreviations: SD (standard deviation), LNA (alpha-linolenic acid), tr - trace (area <0.05\%).

\section{Quantification of fatty acid methyl esters (FAME)}

The concentration of fatty acids in $\mathrm{mg} \cdot \mathrm{g}^{-1}$ of total lipids in liver tissue was measured against tricosanoic acid methyl ester (23:0) from Sigma (USA) as an internal standard as described by Joseph and Ackman (1992). The following formula was used to calculate the concentrations:

$$
F A\left(m g \cdot g^{-1} T L\right)=\frac{A_{X} \times W_{I S} \times C F_{X}}{A_{I S} \times W_{X} \times C F_{E A}}
$$

where TL is total lipids, $A_{X}$ is the peak area of fatty acids, $A_{I S}$ is the peak area of the internal standard (IS) tricosanoic acid methyl ester (23:0), $\mathrm{W}_{\mathrm{IS}}$ is the weight $(\mathrm{mg})$ of IS added to the sample (in $\mathrm{mg}$ ), $\mathrm{W}_{\mathrm{X}}$ is the sample weight (in $\mathrm{mg}$ ), $\mathrm{CF}_{\mathrm{X}}$ is the theoretical correction factor, and $\mathrm{CF}_{\mathrm{EA}}$ is the correction factor of methyl ester for fatty acids.

\section{Statistical analysis}

The values of the means were statistically compared by Tukey's test at 5\% with one-way ANOVA. Data were processed using the Statistica software 7.0 (StatSoft, Statistica, 2005).

\section{RESULTS AND DISCUSSION}

The total lipid contents in the diet were $7.76 \%$ (commercial diet) and $7.60 \%$ (linseed diet) (Table 1). A total of 13 fatty acids were identified in the commercial and linseed oil diets, and the major fatty acids were LA, oleic acid (18:1n-9), LNA, palmitic acid (16:0), and stearic acid (18:0). The commercial diet had the highest amount of LA $(57.09 \%)$ and the replacement of sunflower oil with linseed oil increased the proportions of 18:3n3 from $2.92 \%$ (commercial diet) to $26.97 \%$ (linseed oil diet). 
The total lipids contents of mouse livers (Table 2) were $4.41 \%$ (commercial diet) against a mean value of $4.24 \%$ (linseed oil diet) and they did not differ significantly $(p>0.05)$. The quantitative analysis of FA of livers, expressed in mg of fatty acids per gram of total lipid (mg/g TL), is presented in Table 2 and the qualitative analysis is shown in Figure 1. A total of $22 \mathrm{FA}$ were identified in the livers of mice fed with the commercial and linseed oil diet (Fig. 1). The major FA were 16:0 and 18:0 (saturated), 18:1n-9 and 18:1n-7 (monounsaturated), 18:2n-6 (diunsaturated), and the prevailing long-chain polyunsaturated FA (LC-PUFA) were arachidonic acid (20:4n-6) and docosahexaenoic acid (DHA, 22:6n-3).

$\underline{\text { Table } 2 \text { - Total lipids content, weight, and fatty acid composition of mouse livers. }}$

\begin{tabular}{|c|c|c|c|c|c|c|}
\hline & \multirow{2}{*}{$\begin{array}{c}\text { Commercial } \\
\text { diet } 0 \text { day }\end{array}$} & \multicolumn{5}{|c|}{ Linseed oil diet } \\
\hline & & 7 days & 14 days & 28 days & 42 days & 56 days \\
\hline TL (\%) & $4.41 \pm 0.91$ & $4.37 \pm 0.09$ & $4.43 \pm 0.85$ & $3.98 \pm 0.20$ & $4.02 \pm 0.22$ & $4.38 \pm 0.02$ \\
\hline Liver weight (g) & $2.2 \pm 0.3$ & $2.2 \pm 0.3$ & $2.5 \pm 0.3$ & $2.8 \pm 0.4$ & $2.9 \pm 0.4$ & $2.8 \pm 0.3$ \\
\hline \multicolumn{7}{|l|}{ Fatty acids ${ }^{A}$} \\
\hline $14: 0$ & $1.58 \pm 0.07$ & $1.62 \pm 0.40$ & $1.49 \pm 0.71$ & $1.85 \pm 0.57$ & $1.61 \pm 0.14$ & $1.15 \pm 0.15$ \\
\hline $15: 0$ & $0.32 \pm 0.45^{\mathrm{a}}$ & $0.56 \pm 0.06^{\mathrm{a}}$ & $1.03 \pm 0.09^{\mathrm{b}}$ & $0.94 \pm 0.24^{\mathrm{b}}$ & $0.78 \pm 0.07^{\cdot b}$ & $0.92 \pm 0.04^{b}$ \\
\hline $16: 0$ & $157.46 \pm 0.20^{\mathrm{a}}$ & $175.53 \pm 3.31^{\mathrm{b}}$ & $171.27 \pm 1.75^{\text {a.b }}$ & $175.40 \pm 3.03^{\mathrm{b}}$ & $161.10 \pm 7.56^{\mathrm{a}}$ & $167.07 \pm 7.83^{a . b}$ \\
\hline $16: 1 n-9$ & $2.95 \pm 0.12^{a . b}$ & $2.03 \pm 0.14^{\mathrm{a} . \mathrm{b}}$ & $1.91 \pm 0.28^{\mathrm{a} . \mathrm{b}}$ & $2.90 \pm 0.76^{\mathrm{b}}$ & $2.47 \pm 0.12^{\mathrm{b}}$ & $2.28 \pm 0.11^{\mathrm{b}}$ \\
\hline $16: 1 n-7$ & $8.55 \pm 0.10$ & $8.49 \pm 2.30^{b}$ & $8.16 \pm 0.20^{\mathrm{a} . \mathrm{b}}$ & $11.82 \pm 0.45^{\mathrm{b}}$ & $7.07 \pm 0.64^{\mathrm{a}}$ & $6.50 \pm 0.56^{\mathrm{a}}$ \\
\hline $17: 0$ & $1.62 \pm 0.05^{\mathrm{a} . \mathrm{b}}$ & $1.26 \pm 0.13^{b . c}$ & $1.53 \pm 0.02^{\text {a.b.c }}$ & $1.06 \pm 0.29^{c}$ & $1.78 \pm 0.07^{\mathrm{a} . \mathrm{d}}$ & $2.26 \pm 0.01^{\mathrm{d}}$ \\
\hline 18:0 & $69.46 \pm 0.74^{a . b}$ & $74.75 \pm 3.05^{\text {a.d }}$ & $73.42 \pm 2.54^{\text {a.b.d }}$ & $61.84 \pm 6.25^{\mathrm{b}}$ & $74.33 \pm 2.83^{\mathrm{a}}$ & $87.08 \pm 2.85^{\mathrm{d}}$ \\
\hline $18: 1 n-9$ & $84.99 \pm 0.19^{a}$ & $72.50 \pm 2.30^{\mathrm{a} . \mathrm{b}}$ & $77.32 \pm 2.23^{\mathrm{a} . \mathrm{b}}$ & $75.58 \pm 2.42^{a . b}$ & $68.79 \pm 2.29^{\mathrm{b}}$ & $64.96 \pm 1.56^{\mathrm{b}}$ \\
\hline $18: 1 n-7$ & $15.18 \pm 0.15^{\mathrm{a}}$ & $13.39 \pm 1.39^{\mathrm{a}}$ & $9.18 \pm 1.35^{\text {b.c }}$ & $12.93 \pm 1.87^{\mathrm{a} . \mathrm{b}}$ & $7.17 \pm 0.28^{c}$ & $14.14 \pm 1.71^{\mathrm{a}}$ \\
\hline $18: 2 n-6$ & $111.59 \pm 0.11^{\mathrm{a}}$ & $106.01 \pm 2.19^{\mathrm{a}}$ & $100.56 \pm 0.03^{\mathrm{a}}$ & $123.25 \pm 11.66^{\mathrm{b}}$ & $128.39 \pm 5.07^{\mathrm{b}}$ & $125.29 \pm 3.51^{\mathrm{b}}$ \\
\hline $18: 3 n-6$ & $1.58 \pm 0.16^{\mathrm{a}}$ & $0.52 \pm 0.05^{\mathrm{c}}$ & $0.77 \pm 0.17^{\text {b.c }}$ & $0.92 \pm 0.18^{\text {c.d }}$ & $1.43 \pm 0.23^{\mathrm{e}}$ & $1.14 \pm 0.15^{\text {d.e }}$ \\
\hline $18: 3 n-3($ & $1.29 \pm 0.11^{\mathrm{a}}$ & $11.86 \pm 1.82^{\mathrm{b}}$ & $14.67 \pm 2.84^{\mathrm{b}}$ & $25.87 \pm 1.13^{\mathrm{c}}$ & $20.51 \pm 1.12^{\mathrm{d}}$ & $18.90 \pm 0.71^{\mathrm{e}}$ \\
\hline $20: 1 n-9$ & $2.05 \pm 0.31^{\mathrm{a}}$ & $1.45 \pm 0.08^{\text {a.b.c }}$ & $1.04 \pm 0.29^{\mathrm{c}}$ & $1.27 \pm 0.19^{\mathrm{b} . c}$ & $1.66 \pm 0.21^{\text {a.b }}$ & $1.89 \pm 0.02^{\mathrm{a}}$ \\
\hline & $\begin{array}{l}2.45 \pm 0.03^{\mathrm{a}} \\
6.67 \pm 0.11^{\mathrm{a}}\end{array}$ & & $\begin{array}{l}1.33 \pm 0.22^{\mathrm{b}} \\
7.85 \pm 0.39^{\text {a.b }}\end{array}$ & & $\begin{array}{l}1.88 \pm 0.18^{\mathrm{a} . \mathrm{b}} \\
7.99+0.27^{\mathrm{b}}\end{array}$ & $\begin{array}{l}1.99 \pm 0.01^{\text {a.b }} \\
8.88+0.57^{\text {a.b }}\end{array}$ \\
\hline $20: 4 n-6$ (AA) & $89.01 \pm 0.20^{\mathrm{a}}$ & $44.87 \pm 0.61^{b}$ & $45.36 \pm 3.28^{b}$ & $43.69 \pm 5.59^{b}$ & $44.89 \pm 1.95^{b}$ & $54.22 \pm 2.31^{b}$ \\
\hline $20: 2 n-6$ & $1.65 \pm 0.04^{\mathrm{a} . \mathrm{b}}$ & $1.26 \pm 0.05^{\mathrm{c}}$ & $1.32 \pm 0.04^{\mathrm{c}}$ & $1.62 \pm 0.12^{\mathrm{b}}$ & $1.94 \pm 0.09^{\mathrm{d}}$ & $1.90 \pm 0.05^{\mathrm{b} . \mathrm{c}}$ \\
\hline $\begin{array}{l}20: 5 n-3 \text { (EPA) } \\
24: 0\end{array}$ & $\begin{array}{l}0.20 \pm 0.03 \\
5.28 \pm 0.05^{\mathrm{a}}\end{array}$ & $\begin{array}{l}10.48 \pm 0.33^{\mathrm{a}} \\
0.71 \pm 0.15^{\mathrm{b}}\end{array}$ & $\begin{array}{l}10.75 \pm 0.39^{\mathrm{a}} \\
1.09 \pm 0.18^{\mathrm{b}}\end{array}$ & $\begin{array}{l}12.15 \pm 1.30^{b} \\
0.97 \pm 0.31^{b}\end{array}$ & $\begin{array}{l}12.13 \pm 0.39^{\mathrm{b}} \\
1.03 \pm 0.39^{\mathrm{b}}\end{array}$ & $\begin{array}{l}17.51 \pm 0.78^{c} \\
0.75 \pm 0.02^{b}\end{array}$ \\
\hline $24: 1 n-9$ & $14.43 \pm 0.26^{\mathrm{a}}$ & $0.42 \pm 0.02^{\mathrm{b}}$ & $0.48 \pm 0.02^{b}$ & $0.54 \pm 0.09^{\mathrm{b}}$ & $0.51 \pm 0.05^{b}$ & $0.41 \pm 0.02^{b}$ \\
\hline $22: 5 n-3$ & $2.68 \pm 0.04^{\mathrm{a}}$ & $7.37 \pm 0.15^{\mathrm{b}}$ & $8.02 \pm 0.65^{b}$ & $8.66 \pm 1.15^{b}$ & $8.45 \pm 0.39^{b}$ & $11.75 \pm 0.83^{c}$ \\
\hline 22:6n-3 (DHA) & $41.26 \pm 0.44^{\mathrm{a}}$ & $70.43 \pm 0.41^{\mathrm{b}}$ & $73.68 \pm 2.46^{b}$ & $70.89 \pm 3.71^{b}$ & $75.76 \pm 2.09^{b}$ & $95.13 \pm 5.15^{c}$ \\
\hline SFA & $235.72 \pm 0.89^{\mathrm{a}}$ & $254.43 \pm 4.53^{b}$ & $249.83 \pm 3.71^{b}$ & $242.06 \pm 6.99^{\mathrm{a}}$ & $240.63 \pm 8.07^{\mathrm{a}}$ & $259.23 \pm 8.67^{b}$ \\
\hline MUFA & $128.15 \pm 0.50^{\mathrm{a}}$ & $98.28 \pm 7.56^{\text {b.c }}$ & $98.09 \pm 4.35^{\text {b.c }}$ & $105.04 \pm 3.19^{\mathrm{b}}$ & $87.67 \pm 2.41^{\mathrm{c}}$ & $90.18 \pm 2.38^{\text {b.c }}$ \\
\hline PUFA & $258.38 \pm 0.55^{\mathrm{a}}$ & $262.76 \pm 4.13^{\mathrm{a}}$ & $264.31 \pm 4.93^{\mathrm{a}}$ & $296.75 \pm 13.69^{b}$ & $303.37 \pm 5.97^{b}$ & $336.71 \pm 6.70^{c}$ \\
\hline$n-6$ & $206.28 \pm 0.34^{\mathrm{a}}$ & $154.29 \pm 3.14^{\mathrm{b}}$ & $149.34 \pm 4.07^{\mathrm{b}}$ & $171.30 \pm 12.99^{c}$ & $178.53 \pm 5.45^{\mathrm{c}}$ & $184.54 \pm 4.73^{c}$ \\
\hline$n-3$ & $52.10 \pm 0.47^{\mathrm{a}}$ & $108.47 \pm 2.69^{\mathrm{b}}$ & $114.97 \pm 3.95^{\mathrm{b}}$ & $125.45 \pm 4.34^{\mathrm{c}}$ & $124.84 \pm 2.45^{\mathrm{c}}$ & $152.17 \pm 5.52^{\mathrm{d}}$ \\
\hline PUFA/SFA & $1.10 \pm 0.01^{\mathrm{a}}$ & $1.03 \pm 0.02^{\mathrm{a}}$ & $1.06 \pm 0.03^{\mathrm{a}}$ & $1.23 \pm 0.07^{\mathrm{b}}$ & $1.26 \pm 0.05^{\mathrm{b}}$ & $1.30 \pm 0.05^{\mathrm{b}}$ \\
\hline$n-6 / n-3$ & $3.96 \pm 0.03^{\mathrm{a}}$ & $1.42 \pm 0.05^{\mathrm{b}}$ & $1.30 \pm 0.06^{\mathrm{b}}$ & $1.37 \pm 0.11^{\mathrm{b}}$ & $1.43 \pm 0.05^{\mathrm{b}}$ & $1.27 \pm 0.07^{\mathrm{b}}$ \\
\hline
\end{tabular}

${ }^{\mathrm{A}}$ Value (mg fatty acids/gram of the total lipids) as an average of 36 replicate analyses. Averages followed by different letters in the same line are significantly different $(\mathrm{p}<0.05)$ by Tukey's test. Abbreviations: $\operatorname{tr}-($ trace $<0.2)$, SFA (saturated fatty acid), MUFA (monounsaturated fatty acid), PUFA (polyunsaturated fatty acid), n-6 (omega-6), n-3 (omega-3). 


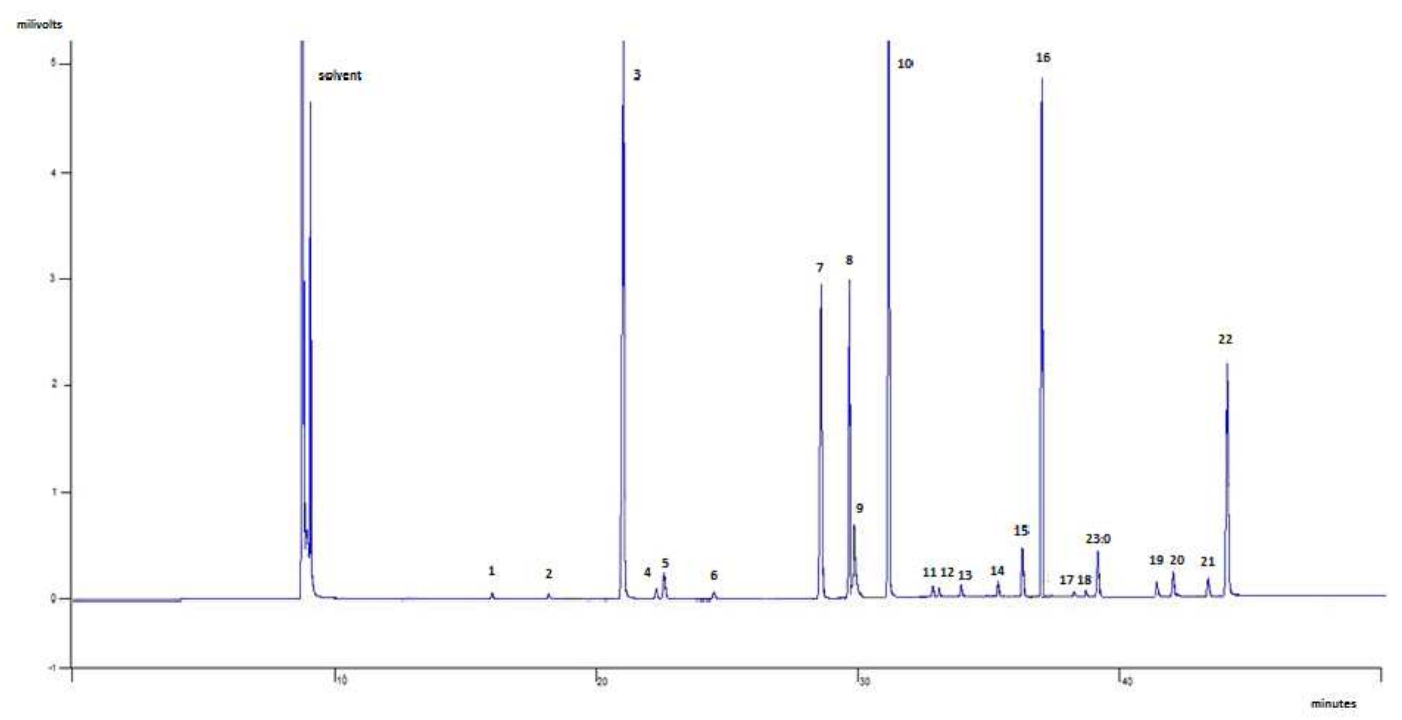

Figure 1 - Representative chromatogram of mouse liver's fatty acid methyl esters. (1) 14:0; (2) 15:0; (3) 16:0; (4) 16:1n-9; (5) 16:1n-7; (6) 17:0; (7) 18:0; (8) 18:1n-9; (9) 18:1n-7; (10) 18:2n-6; (11) 18:3n-6; (12) 18:3n-3; (13) 20:1n-9; (14) 20:3n-6; (15) 20:3n-3; (16) 20:4n-6; (17) 20:2n-6; (18) 20:5n-3; (19) 24:0; (20) 24:1n-9; (21) 22:5n-3 and (22) $22: 6 n-3$.

LNA is a precursor of the n-3 fatty acid series. Only LNA was present in the feeds in this experiment (Table 1). The level of LNA, in mouse livers was $1.29 \mathrm{mg} / \mathrm{g}$ (commercial diet), and under the linseed diet, it increased from $11.86 \mathrm{mg} / \mathrm{g}$ (7 days) to $18.90 \mathrm{mg} / \mathrm{g}$ (56 days). The highest value of LNA was at 28 days $(25.87 \mathrm{mg} / \mathrm{g})$. After that, the values decreased to $20.51 \mathrm{mg} / \mathrm{g}$ (42 days) and $18.90 \mathrm{mg} / \mathrm{g}$ (56 days). Part of LNA was converted into n-3 FA series (20:3n-3, EPA, 22:5n-3, and DHA) and some of the LNA were stored in the livers rather than converted. For the commercial diet, the 20:3n-3, EPA, 22:5n-3, and DHA levels were lower than the lowest values for the linseed oil diet. The highest values as a function of feeding duration were for LNA $[25.87 \mathrm{mg} / \mathrm{g}(28$ days), EPA, $17.51 \mathrm{mg} / \mathrm{g}$ (56 days), and DHA, $95.13 \mathrm{mg} / \mathrm{g}$ (56 days)]. The AA level (Table 2) of the commercial diet was $89.01 \mathrm{mg} / \mathrm{g}$ against 46.60 $\mathrm{mg} / \mathrm{g}$ (medium value) for the linseed oil diet $(p<0.05)$; however, they did not differ significantly ( $>0.05$ ) with feeding duration.

The reduction of the AA content following dietary LNA supplementation is well documented (Rambjor et al., 1996). During the last 40 years, the ratio of dietary (n-6) to (n-3) FA in the industrialized societies has increased because of increased consumption of vegetable oils rich in $n-6$ (Surette, 2008). The estimated consumption ratio of $n-6 / n-3$ is $9.8: 1$. It has been determined on the basis of USA diet, which is much higher than the current recommendation (i.e., 2.3:1). Many countries, diet have n-6/n-3 ratio from 10:1 to 20:1 (Simopoulos, 2002), with cases up to 50:1 (Simopoulos, 2004). There are several recommendations $(2: 1$ to $10: 1)$ for $n-6 / n-3$ ratio (Simopoulos et al., 1999; Schaefer et al., 2002; Chardigny et al., 2001; NCM, 1996; Matin et al., 2006). However, there is still no consensus for ideal ratio of $n-6$ to $n-3$. Thus, there is need to stress that 2.3:1 ratio recommendation is made to maximize the conversion of ALA to DHA (Masters, 1996). This could be achieved by a 4fold increase in fish consumption (Kris-Etherton et al., 2000). In the present study, n-6/n-3 ratio fell approximately 3 -fold for 56 days.

The analysis of the sums and ratios is presented in Table 2. Concerning the feeding duration effect in the initial days, specifically between day 0 (commercial diet with sunflower oil) and day 7 (linseed oil diet), the sums of the n-6, n-3 and n6/n-3 ratio varied abruptly, the $n-6$ sums decreased from $206.26 \mathrm{mg} / \mathrm{g}$ (day 0) to $154.28 \mathrm{mg} / \mathrm{g}$ (7 days), and the $\mathrm{n}-3$ sums increased from $52.10 \mathrm{mg} / \mathrm{g}$ (day 0) to $108.47 \mathrm{mg} / \mathrm{g}$ (7 days), thus explaining the decrease of $n-6 / n-3$ ratios from 3.96 to 1.42 . For the linseed oil diet, from days 28 to 56, the PUFA, $\mathrm{n}-6, \mathrm{n}-3$ values and PUFA/SFA ratio increased 
$(\mathrm{p}<0.05)$ in relation to day 7 , and the $\mathrm{n}-6 / \mathrm{n}-3$ ratio remained constant. However, in 56 days, PUFA and $\mathrm{n}-3$ peaked at 336.71 and $152.17 \mathrm{mg} / \mathrm{g}$, respectively.

Table 3 shows the ratio variation for LNA, EPA, and DHA concentrations with time $(7,14,28,42$, and 56 days) as a function of the concentration at day $0(1.29 \mathrm{mg} / \mathrm{g})$. The highest value of LNA at 28 days was 20.05 times higher than that at 0 day. The EPA and DHA values were 87.55 and 2.31 times higher at 56 days, respectively. This indicated that the background diets were highly influenced by the feeding duration.

Table 3 - Ratios of LNA, EPA and DHA concentrations as a function of feeding duration relative to the day 0 concentration.

\begin{tabular}{ccccccc}
\hline Fatty acids & $\begin{array}{c}\text { Commercial diet } \\
\text { (mg/g LT) 0 day }\end{array}$ & $\begin{array}{c}\text { Ratio I } \\
\text { (7 days/0 day) }\end{array}$ & $\begin{array}{c}\text { Ratio II } \\
(\mathbf{1 4} \text { days/0 day) }\end{array}$ & $\begin{array}{c}\text { Ratio III } \\
(\mathbf{2 8} \text { days/0 day) (42 days/0 day) }\end{array}$ & $\begin{array}{c}\text { Ratio (56 days/0day) } \\
\text { (5) }\end{array}$ \\
\hline $18: 3 \mathrm{n}-3$ (LNA) & 1.29 & $9.19^{\mathrm{a}}$ & $11.37^{\mathrm{b}}$ & $20.05^{\mathrm{c}}$ & $15.90^{\mathrm{d}}$ & $14.65^{\mathrm{e}}$ \\
20:5n-3 (EPA) & 0.20 & $52.40^{\mathrm{a}}$ & $53.75^{\mathrm{a}}$ & $60.75^{\mathrm{b}}$ & $60.65^{\mathrm{b}}$ & $87.55^{\mathrm{c}}$ \\
\hline $22: 6 \mathrm{n}-3$ (DHA) & 41.26 & $1.71^{\mathrm{a}}$ & $1.79^{\mathrm{a}}$ & $1.72^{\mathrm{a}}$ & $1.84^{\mathrm{a}}$ & $2.31^{\mathrm{b}}$ \\
\hline
\end{tabular}

Values followed by different letters in the same line are significantly different $(\mathrm{p}<0.05)$ by Tukey's test. Abbreviations: LNA (alpha-linolenic acid), EPA (eicosapentaenoic acid), DHA (docosahexaenoic acid).

The effects of the substitution of sunflower oil $(3 \%, w / w)$ with linseed oil $(3 \%, w / w)$ in mouse feed for 56 days resulted in significantly different concentrations of FA in the liver. Linseed oil feed afforded an increase in the concentration of n-3 FA and a decrease in the concentration of n-6 FA during the feeding. The results also indicated a variation in FA concentrations with time during the feeding.

\section{ACKNOWLEDGMENTS}

We are thankful to the Coordenação de Aperfeiçoamento de Pessoal de Nível Superior (CAPES).

\section{REFERENCES}

Bligh, E.G. and Dyer, W.J. (1959), A rapid method of total lipid extraction and purification. Can. J. Biochem., 37, 911-917.

Calder, P. (2006), N-3 Polyunsaturated fatty acids, inflammation, and inflammatory diseases. A. J. Clin. Nutr., 83(suppl), 1505S-1519S.

Carl, J.L.; Richard, V.M.; Mandeep, R.M. and Hector, O.V. (2009), Omega-3 polyunsaturated fatty acids and cardiovascular diseases. J. Am. Coll. Cardiol., 54, 585-594.
Chapkin, R.S.; Kim, W.; Lupton, J.R. and McMurray, D.N. (2009), Dietary docosahexaenoic and eicosapentaenoic acid: Emerging mediators of inflammation. Prost. Leuk. Essent Fatty Acids, 81, 187-191.

Chardigny, J. M., Bretilooon, L., Sébédio, J. L., (2001), Newinsights in health effects of trans alpha-linolenic acid isomers in humans. Eur. J. Lipids Sci. Technol., 103, 478-482.

Cunniff, P.A. (1998), Official Methods of Analysis of AOAC International. 16. ed., Association of Official Analytical Chemists, Arlington, CD-Rom.

de Souza, N.E.; Stevanato, F.B.; Garcia, E.E.; Visentainer, J.E.L.; Zara, R.F. and Visentainer, J.V. (2008), Supplemental dietary flaxseed oil affects both neutral and phospholipid fatty acids in cultured tilapia. Eur. J. Lipid Sci. Technol., 110, 707-713.

Garófolo, A. and Petrilli, A.S. (2006), Balanço entre ácidos graxos ômega-3 e 6 na resposta inflamatória em pacientes com câncer e caquexia. Rev. Nutr., 19, 611-621.

Harnack, K.; Andersen, G. and Somoza, V. (2009), Quantitation of alpha-linolenic acid elongation to eicosapentaenoic and docosahexaenoic acid as affected by the ratio of $\mathrm{n} 6 / \mathrm{n} 3$ fatty acids. Nutr. Metabol., 6, 1-11.

Harris, W.S. (1997), N-3 fatty acids and serum lipoproteins: animal studies. Am. J. Clin. Nutr., 65 (suppl), 1611S-1616S.

Innis, S.M. (2007), Fatty acids and early human development. Early Hum. Dev., 83, 761-66. 
James, M.; Gibson, R. and Cleland, L. (2000), Dietary polyunsaturated fatty acids and inflamamatory mediator production. Am. J. Clin. Nutr., 72 (supply), 343S-348S.

Joseph, J.D. and Ackman R.G. (1992), Capillary column gas chromatography method for analysis of encapsulated fish oil and fish oil ethyl esters: collaborative study. J. AOAC Inter., 75, 488-506.

Kris-Etherton, P.M.; Taylor, D.S.; Yu-Poth, S.; Huth, P.; Moriarty, K.; Fishell, V.; Hargrove, R.L.; Zhao, G. and Etherton, T.D. (2000), Polyunsaturated fatty acids in the food chain in the United States. Am. J. Clin. Nutr., 71, 179S-188S.

Leon, L.R. (2005), The use of gene knockout mice in thermoregulation studies. J. Thermal Biol., 30, 273288.

Maia, E.L and Rodriguez-Amaya, D.B. (1993), Avaliação de um método simples e econômico para a metilação de ácidos graxos com lipídios de diversas espécies de peixe. Rev Instituto Adolfo Lutz. 53, 2735.

Martin, C. A.; Almeida, V. V.; Ruiz, M. R.; Visentainer, J. E. L.; Matsushita, M.; de Souza, N. E.; Visentainer, J. V. (2006), Ácidos graxos poliinsaturados ômega-3 e ômega-6: importância e ocorrência em alimentos. Rev. Nutr., 19, 761-770.

Martin, C.A.; de Oliveira, C.C.; Visentainer, J.V.; Matsushita, M. and de Souza, N.E. (2008), Optimization of the selectivity of a cyanopropyl stationary phase for the gas chromatographic analysis of trans fatty acids. J. Chromatogr. A, $1194,111-$ 117.

Masters, C. (1996), Fatty acids and peroxisome. Mol. Cell Biochem., 165, 83-93.

NCM (Nordic Council os Ministers), (1996), Nordic nutrition recommendations. Scand. J. Nutr., 40, 161165.

Qiu, X. (2003), Biosynthesis of docosahexaenoic acid (DHA, 22:6-4,7,10,13,16,19): two distinct pathways. Prost. Leuk. Essent Fatty Acids, 68, 181-65.

Rambjor, G.S.; Walen, A.I.; Windsor, S.L. and Harris, W.S. (1996), Eicosapentaenoic acid is primarily responsible for hypotriglyceridemic effect of fish oil in Human. Lipids., 31, S45-S49.
Schaefer, E. J., (2002), Lipoproteins, nutrition, and heart disease. Am. J. Clin. Nutr., 75, 191-212.

Schaeffer, L.; Gohlke, H.; Müller, M.; Heid, I.M.; Palmer, L.J.; Kompauer, I; Demmelmair, H.; Illig, T.; Koleyzko, B. and Heinrich, J. (2006), Common genetic variants of the FADS1 FADS2 gene cluster and their reconstructed haplotypes are associated with the fatty acid composition in phospholipids. Hum. Mol. Gen., 15, 1745-1756.

Simopoulos, A. P., (2002), Omega-3 fatty acids in wild plants, nuts and seeds. Asia Pacific J. Clin. Nutr., 11(S2), S163-S173.

Simopoulos, A. P., (2004), Omega-6/omega-3 essential fatty acid ratio and chronic diseases. Food Rev. Inter., 20, 77-90.

Simopoulos, A. P., Leaf, A., Salem, N., (1999), Essentiality and recommended dietary intakes for omega-6 and omega-3 fatty acids. Ann. Nutr. Metabol., 43, 127-130.

StatSoft, Statistica 7.0 Software (2005), Tucksa; StatSoft.

Surette, M.E. (2008), The science behind dietary omega-3 fatty acids. Can. Med. Assoc. J., 178, 177180.

Tonial, I.B.; Stevanato, F.B.; Matsushita, M.; de Souza, N.E.; Furuya, W.M.; Visentainer, J.V. (2009), Optimization of flaxseed oil feed time length in adult Nile tilapia (Oreochromis niloticus) as a function of muscle omega-3 fatty acids composition. Aquacult. Nutr. 15, 564-568.

Vancassel, S.; Blondeau, C.; Lallemand, S.; Cador, M.; Linard, A.; Lavialle, M. and, Dellu-Hagedorn, F. (2007), Hyperactivity in the rat is associated with spontaneous low level of $n-3$ polyunsaturated fatty acids in the frontal córtex. Behav. Brain Res., 180, 119-126.

Visentainer, J.V.; de Souza, N.E.; Makoto, M.; Hayashi, C. and Franco, M.R.B. (2005), Influence of diets enriched with flaxseed oil on the $\alpha$-linolenic, eicosapentaenoic and docosahexaenoic fatty acid in Nile tilapia (Oreochromis niloticus). Food Chem., 90, 557-560.

Received: December 08, 2009; Revised: July 29, 2010; Accepted: January 06, 2011. 